\title{
Research on the Innovation of Ideological and Political Education Mode in Colleges in the Data Era
}

\author{
Li Li \\ NanChang Institute of Science \& Technology, Nanchang,330108
}

Keywords: Big data; Colleges; Ideological and political education; Innovation

\begin{abstract}
With the rapid development and extensive application of big data, the ideological and political education work in colleges has not only brought about the characteristics including date of classroom teaching, the extracurricular exchange network, the sharing of thought and information, but inevitably face the negative impact of big data on ideological and political education, the role of ideological and political theory and the effect of weakening the traditional ideological and political education methods are increasingly small and other new issues. In this regard, we should innovate the new path of ideological and political education in colleges from the aspects of constructing healthy network environment, cultivating quality education team and create characteristic network platform.
\end{abstract}

\section{Introduction}

Since 2013, the word "big data" has gradually entered our field of vision. As with the invention of the Internet, big data brought about not only the revolution of information technology, but also the changes in all aspects of society. For the field of education, big data is not only a new educational technology, but also a new educational carrier, so how to use the opportunity brought about by the era of big data education reform is essential. Big data has the characteristics of a wealth of information, rich in content, diverse forms and fast spread, wide range, uncontrollable and so on. Affected by this, college ideological and political education had a huge change in educational resources, teaching methods, carriers, paths, etc. At present, the discussion on the innovation of ideological and political education in colleges and universities in the era of big data is mainly based on how to explore and use big data from the technical level and apply its value to the ideological and political education.

\section{The Connotation and Characteristics of Big Data}

A unified definition of the connotation and definition of the term of big data has not yet been given in the field of related research, in general, big data can be understood as a data set, which contains a huge and can be used information resources, the corresponding information has shown a variety of characteristics. In the current application practice, big data technology can lay a technical foundation for realizing the full excavation of information resources and realizing the improvement of data information as a whole and efficient analysis and storage. Especially in the network era, as the product of the information revolution, it will once again cause profound changes in the field of technology. The big data age has the characteristics as follow:

First, the amount of information is big but the quality is uneven. Based on the era of big data, with the network to promote the dissemination of information, it has broken the constraints of time and space, and thus can provide the necessary areas for social information resources, but the uneven of corresponding information quality, false violence and pornographic information content eroded people and get the user in trouble, so how to achieve the required information on the effective choice has become a major distress.

Second, the speed of information dissemination and updating and the ability to achieve multi-channel access. First of all, in the dissemination of information, with the help of computer network technology, information shows a burst of growth, both in communication and on the 
update, they are very fast, how to use this information to serve the study is a big outstanding problem for the ideological and political education work in colleges.

Third, the impact of people's thinking. Based on the diversified network information, the impact of people's thinking, coupled with the contemporary college students as the main body of network applications, the formation of ideological point of view and value concept are integrated into a variety of ideas and gradually generated, and inevitably foreign ideas will have a certain impact on college students' thinking and impact.

\section{New Problems in Ideological and Political Education in Colleges under the Big Data Era}

Big data technology provide a convenient for ideological and political education to improve the effectiveness in colleges in the teaching methods and other aspects, but also have a certain impact on the education concept and ideological idea of teachers and teachers, bringing varying degrees of challenge.

The Negative Impact of Big Data on the Ideological and Political Education. When big data bring a wealth of education and teaching resources for the ideological and political education, but also bring a certain negative impact, which is mainly reflected in the "three values" of college students. In the period of formation world outlook, outlook on life and values of college students, they are active in thinking, vision, with a strong plasticity; but at the same time they have not mature thinking, lack of rational thinking, the ability of things to identify is not strong, and thus more vulnerable to adverse thoughts and words and deeds of the outside world, prone to bias or even to the extreme.

The Role the Effect of Weakening of Ideological and Political Theory. With the process of the reform and opening up and communication and cooperation at home and abroad, the foreign trend of thought has also had a profound impact on the ideological ideas of contemporary college students, and the educational guidance and effect of ideological and political theory have been weakened. The subject position of teachers of ideological and political theory. Most of the traditional ideological and political teaching using classroom teaching mode, taught by the teacher one-way teaching to complete the content of classroom teaching is also derived from textbooks or radio and television, teachers in a complete dominant position. In the era of big data, due to the popularity of the network and the miniaturization and popularization of the network terminals, the media and means of receiving the information are greatly increased, and the dependence on the teachers is reduced.

The Traditional Ideological and Political Education Methods are Declining. The traditional method of ideological and political education has been very successful in practical teaching activities after long-term exercise and application, but with the development of the times, there are some places that are out of touch with reality. First, teaching methods and ideas need to be updated. In the traditional classroom teaching mode, the teachers use the "indoctrination" and "preaching" methods to impart knowledge, lead to the low participation of students, the interaction between teachers and students seriously affect the classroom teaching effect. In the era of big data, the way of obtaining knowledge and the media is very broad, and the autonomy of students 'learning is greatly improved. This puts forward higher requirements for teachers' teaching work, and the teaching methods need to be innovated and innovated before.

\section{Effective Ways of Innovating Ideological and Political Education in Colleges under Big Data}

The ideological and political education workers in colleges and universities should grasp the opportunities brought by the great data age, and make corresponding adjustments in the way of thinking, education methods and means in time. To adapt to the new situation, innovate ideological and political education methods, big data and ideological and political education combined together to improve the scientificity and effectiveness of ideological and political education.

Change the Way of Thinking, and Establish the Awareness of Big Data. In the era of big data, ideological and political education workers in the relevant departments of colleges should 
constantly change their way of thinking, update their ideas and, establish a big data awareness, fully understand the value of big data for ideological and political education, attach great importance to the importance of big data for ideological and political education And the ability to enhance their sensitivity to data information. Counselors are to learn big data technology, cultivate their own data thinking and big data processing capacity, through the data to directly understand the ideological and behavioral status interpersonal relationships and social interaction context, living needs of college students, comprehensively understanding educational objects and accurate grasp, to enhance the relevance of education to provide real effective basis, so as to promote the perfect data and education docking.

Carrying out Personalized Education. In the era of big data, the ideological and political education workers in colleges can understand the ideological behavior, value orientation, personal hobbies and psychological situation of each student through the analysis of the data. The understanding and grasp of these situations are helpful to the ideological and political education workers, Change the way, for different educators to take different educational strategies. Under the influence of big data thinking, the essence of education will return to promote the development of individual education objects. The educational model will realize the development from the traditional classroom collective teaching to the digital personality education.

\section{The Establishment of Big Data Education Research Platform}

The method of ideological and political education not only includes the methods of obtaining and analyzing ideological information, but also contain the decision-making, implementation and evaluation methods of ideological and political education. Through the establishment of big data education research platform, colleges can achieve the integration of educational information. In the acquisition and analysis of students' ideological information, colleges can communicate with different functions such as library, educational office and dormitory center to realize the analysis of information, so as to realize the innovation of information acquisition and analysis method of ideological and political education. In the decision-making and implementation of ideological and political education, colleges can realize the sharing and cooperation of data resources between schools and inter-school through big data education research platform, construct the ideological and political education chain and innovate the decision-making and implementation of ideological and political education, to improve the scientificity of ideological and political education decision-making and the implementation.

\section{Conclusion}

Based on the background of big data, it is necessary to make full use of big data technology to realize the innovation of ideological and political education work, and then depend on the advantages of big data technology to realize the innovation of ideological and political education mode and enhance the service quality, so it is necessary to clearly know the basis of the opportunities and challenges brought about by big data age to the ideological and political education in the work, and actively use this technology to achieve the construction of a new job camp, and based on big data technology down to achieve the continuous innovation of the work, and thus can fundamentally play the positive role in the ideological and political education in the development of colleges.

\section{References}

[1] Hong L I. The Path Selection of the Training Mode of Applied Talents in Ideological and Political Education of Nationalities University[J]. Journal of Gansu Normal Colleges, 2016.

[2] Wang D H, Yang H M, Zhou X J. The Impact of of Campus Media Convergence Development on Ideological and Political Education of University[J]. China Agricultural Education, 2016. 
[3] Dong H H. Ecological Fusion: The New Realm of University Network Ideological and Political Education in Mobile Internet[J]. Journal of South China Normal University, 2015.

[4] LI Hong-cong. Research on System Construction of Practice Base for Ideological and Political Education in University[J]. Journal of Baicheng Normal University, 2015.

[5] Song W, Qiao J, Li L, et al. Exploration of ways in Ideological and Political Education in University and Research on Entrepreneurship Education[C]// International Conference on Education, Management, Information and Medicine. 2015.

[6] Yi W, Yang Y. Research on the Psychological Counseling Method of Ideological and Political Education of Modern University Students[C]// International Conference on Management, Education, Information and Control. 2015.

[7] Lin L, Li M G. Strengthen the Integrity Education of University Students and Promote the College Ideological and Political Education[C]// International Conference on Social Science, Education Management and Sports Education. 2015.

[8] Wang Y, University T T. Primacy Effects and the New University Students' ideological and Political Education[J]. Modern Education Science, 2015.

[9] Wang F M, Cheng-Hai Y U. Comparison and Enlightenment of University Students' Ideological and Political Education Approach in China and USA[J]. Journal of Hubei Correspondence University, 2015.

[10] Gong G J, Luo L S. Study on Education of Employment Outlook in Ideological and Political Work of University[J]. Journal of Baicheng Normal University, 2015.

[11] Shou-Xiang L I. The Research on the Ideological and Political Education Function of University Campus Media[J]. Journal of Hubei Correspondence University, 2015.

[12] Fu W. Analysis on the Mode of Ideological and Political Education for University Students with Dormitories as the Carrier[J]. Science Education Article Collects, 2015. 